\title{
Experiential, Collaborative And Team Projects: Communication Audits In The MBA Communication Course
}

\author{
Claudia Hart, Northern Michigan University, USA \\ Margo Vroman, Northern Michigan University, USA \\ Karin Stulz, Northern Michigan University, USA
}

\begin{abstract}
In this paper the authors discuss the challenges and rewards of building a graduate level Managerial Communication course around an experiential communication audit project. The purpose of the project was to provide MBA (Master of Business Administration) students with exposure to the real world responsibilities and demands of working in a complex organization while simultaneously demonstrating the crucial role that good communication plays in any organization. In this service-learning project, student teams collaborated with non-profit organizations to analyze communication effectiveness and offer suggestions for improvement. Participating students acknowledged their increased skills in the areas of communication, teamwork, interviewing, research and analysis. These students will be very marketable graduates who will become highly valued employees.
\end{abstract}

Keywords: Communication Audit; Experiential; Team-Based; Service Learning; Collaborative Learning

\section{INTRODUCTION}

$\mathscr{I}$ $\mathrm{n}$ her article, Executive Perceptions of the Top 10 Soft Skills Needed in Today's Workplace, Marcel Robles (2012) identifies the ten most important soft skills business executives seek in employees. These are integrity, communication, courtesy, responsibility, social skills, positive attitude, professionalism, flexibility, teamwork, and work ethic. Of these, her research concluded that integrity and communication skills were the most important qualities desired by today's employers. In addition, employers want resourceful employees who have the ability to collaborate, motivate, and empathize with their colleagues. Business leaders, she notes, often complain that today's graduates do not possess good verbal and nonverbal communication skills or interview abilities. Obviously then, graduates who can demonstrate interpersonal and communication skills, the ability to work collaboratively with colleagues and pacify unhappy customers will have a much better chance of obtaining employment than those who cannot (Glenn, 2008; Employers Value Communication, 2004; Perreault, 2004). Providing an educational experience that develops these qualities by integrating both technical skills and soft skills in a real world environment will prepare graduates who have a significant advantage over their peers. A communication audit project in the communication course provides just such an educational experience.

When an MBA program was launched at a regional public university in the Midwestern United States, the Managerial Communication course was one of the first courses offered in their 15 -week semester. The previous year, one of the authors was assigned to develop and teach the course. In an effort to design an educational experience that offered a significantly different, higher-level experience than the required undergraduate managerial communication course, a communication audit project was explored. Even though the professor had never conducted a communication audit, the idea of framing the course around this type of project was intriguing - an experience that would enable students to acquire significant knowledge about organizational communication through an experiential, collaborative and team-based approach. 
The MBA Managerial Communication course has now been taught four times with the focus on team-based communication audits for organizations in the local community. Despite the logistical challenges of graduate student schedules and organizational work requirements, the benefits clearly outweigh the limitations. In this article, we describe communication audits, how an audit was integrated into our MBA course, identify student outcomes as a result of implementing this experiential, collaborative and team-based service learning project, and offer recommendations and insights for using a communication audit to help students connect classroom theory to workplace practice. As Shelby and Reinsch (1996) say, "While a challenging assignment both for student and professor, the audit is - in our judgment - clearly worth the effort." We concur and highly recommend this approach for teaching a graduate-level communication course. As one student wrote on the course evaluation at the end of the semester, the focus on transitioning our communication style from academic to business was exactly what we needed. The real world experience of the communication audit was something that kept me actively engaged every day!

\section{THE HISTORY AND USE OF COMMUNICATION AUDITS}

Hargie and Tourish (2009) offer a historical perspective of communication audits. Communication audit as a term, first appeared in the early 1950s. This approach for measuring and evaluating organizational performance became popular in the 1970s with significant numbers of publications appearing in academic journals. Academic interest declined during the following two decades when, among many reasons, the primary focus for organizational analysts shifted to theoretical frameworks rather than applied concerns (Mumby \& Stohl, 1996). However, throughout this period, practitioners continued to value and utilize audits for assessing communication effectiveness within organizations. Higher education also continued to include communication audit projects in organizational communication courses (Scott et al., 1999; Shelby and Reinsch, 1996; Zorn, 2002) despite the lack of academic publications.

The contemporary communications audit examines an organization's entire communication environment. This environment not only consists of communication between organizational members, it also includes the cultural, legal and economic conditions of the organization and the sense of security people feel within it. A completed audit provides an organization with a realistic assessment of its strengths and weaknesses as well as valuable information that can be used to reach established goals or create new ones. Hargie and Tourish (2009) "anticipate that both academic and practitioner interest in communication audits will be maintained in the decades ahead" (p. 42).

\section{COMMUNICATION AUDIT}

Most people are familiar with the term 'audit.' As Downs and Adrian (2004) explain, "an audit is merely a process of exploring, examining, monitoring, and evaluating something. Accountants audit financial records, physicians audit patient health, professors audit student learning progress and managers review and audit employee levels of performance" (p. 6). Similarly, a manager can utilize a communication audit to examine communication issues in detail. Today, organizations are eager to improve internal communication (Hargie \& Tourish 2000). As Henderson (2005) says, "the communication audit process is designed to examine and evaluate an organization's communication program; to reveal hurdles to effective communication, to reveal gaps in the communication process, and to provide suggestions for improvement" (p. 12). Communication is the framework in which all production relies; without communication an organization ceases to exist. A communication audit answers the questions where, what, how, and when employees are receiving and sending information as well as the quality of the information transmitted. This process reveals what is working well, what is not working well, and areas that can be improved. Managers can use a communication audit to improve every aspect of their organization's performance.

During a communication audit both quantitative and qualitative data are collected to get the best representation of an organization's communication health. Typical methods used in an audit to make the best assessment include: interviews, surveys, critical incident analysis, network analysis, participant observation, document review, and focus groups (Coffman, 2004). Downs and Adrian recommend using multiple techniques when possible and explain, "the more measures used to collect data, the more reliable are the data; they supplement one another so that the consistency of findings can be tested . . by supplementing one with the other, auditors can ensure that their estimates of the organization are likely to be realistic" (Downs \& Adrian, 2004, p. 27). 
Two very different audit projects have been used during the four semesters this course has been taught. During the first, third and fourth course offerings, small (7-15 employees), nonprofit organizations in the local community participated. During the second course offering, the University had adopted an Action Project for their Academic Quality Improvement Program (AQIP), Developing Feedback Mechanisms and Enhancing Campus Leadership Communication. As an initial component of this continuous improvement initiative, the MBA Managerial Communication students audited the entire university community (approximately 1,200 employees). The process for classroom integration of both types of audits - small and large - will be described.

\section{Communication Audits 1, 3 and 4}

The first step in planning this project for the initial course offering was locating organizations in the community who were willing to welcome MBA students into their company and share their time and information. Teams of students would conduct the entire audit for one organization. For the first course, 14 students enrolled; three organizations seemed like a manageable number with two student teams of five and one team of four. For the third course, 11 students enrolled and two organizations were identified with a team of five and a team of six students assigned to each. The highest enrollment occurred in the fourth course when 18 students enrolled; initially 19 students had registered and three teams of five and one team of four were convened. However, one student in the team of four withdrew from the course a few weeks into the semester and so this team was left with only three members.

Prior to the start of the first course, a list of nonprofit organizations in the community was acquired through the local Chamber of Commerce. Offering this free service to nonprofits seemed like a win-win situation for all participants as nonprofits typically would not have the funds to hire a consultant to evaluate their communication effectiveness. The Chamber's Executive Director offered suggestions of organizations that she believed would be interested in having our students work with them. Many of the organizations had 15 or fewer employees; this number seemed manageable so this was established as the first criterion. Another important criterion was to have nonprofits who would welcome graduate students into their organization and openly share communication issues. A short list of potential organizations was developed and each contact person (typically the Executive Director) was contacted to inquire about interest in this project. Success was achieved with the first few calls. All of the Executive Directors were excited for this opportunity. During the initial meeting with each, a number of issues were emphasized so that the organization as well as the student auditors would have a successful outcome. Management should be willing to:

- commit to following through with all phases of the audit process, culminating with the final oral report to the organization at the end of the semester;

- $\quad$ emphasize to employees the importance of cooperating with graduate students; their open and honest input was necessary to give the audit legitimacy;

- $\quad$ provide access to employees at all levels so that the student teams could collect valid data; this included time for employees to attend an initial meeting to be briefed on the audit, time for employees to complete a survey, participate in a one-on-one interview and/or focus group, and provide additional data as requested by student auditors.

The directors at all three organizations agreed that they wanted to proceed with the audits and were eager to get started. This same process was used for selecting organizations for the audits for Course 3 . For Course 4 , the approach was changed so that student teams were responsible for securing an organization to audit. This added another dimension to student expectations starting with the first day of class. Teams needed to collaborate immediately to generate a list of possible organizations, learn quickly about communication audits so that they could speak confidently with organization decision makers and take initiative to contact and communicate with organizations. Three teams secured organizations within the first two weeks of the class; the fourth team, however, was not able to locate an organization until a month into the semester. This became a valuable learning experience for all students in the class about the importance of initiative, motivation and teamwork as each team was required to orally report on their progress each week. 
The class met one night per week for $3 \frac{1}{2}$ hours for 15 weeks. The book, Assessing Organizational Communication: Strategic Communication Audits (2004), by Downs and Adrian was required reading. Using the procedure suggested by Downs and Adrian for conducting communication audits, a timeline was created to keep the teams on track. Chart 1 shows the schedule for Courses 1 and 3. The schedule was adjusted slightly for Course 4 when teams were required to locate their organization.

Chart 1. Communication Audit Timeline

\begin{tabular}{|l|l|}
\hline Week 1 & Introduction to communication audit \\
\hline Week 2 & Convene student teams, assign organizations to teams \\
\hline Week 3 & Teams plan initial meeting with contact person \\
\hline Week 4 & Teams have completed initial meeting with contact person and report in class \\
\hline Week 5 & $\begin{array}{l}\text { Teams have completed orientation meeting with organization staff and report in class } \\
\text { Teams pretest questionnaire with class }\end{array}$ \\
\hline Week 6 & Teams submit final questionnaire for approval \\
\hline Week 7 & Teams develop interview/focus group guides and plan for on-site interviews \\
\hline Week 8 & Questionnaire data collected and teams report in class \\
\hline Weeks 9-10 & Interviews/focus groups completed and teams report in class \\
\hline Weeks 11-12 & Teams analyze and interpret data and collect additional data, if needed \\
\hline Week 13 & Teams write report and develop oral presentation \\
\hline Week 14 & Teams practice oral presentation with class \\
\hline Week 15 & Teams deliver final oral presentation to organization \\
\hline
\end{tabular}

Students learned about the communication audit process and expected deliverables fairly early in the semester; readings in the Downs and Adrian (2004) text were assigned so that the book was completed by Week 6. During the weekly class sessions, whole group discussions took place to review and clarify the audit process based on the assigned readings. Teams were then required to informally report to the class each week on their activities and outcomes from the previous week. These oral reports were particularly beneficial for the entire class. The teams learned from each other regarding progress, roadblocks, workarounds, and basically, the reality of working with actual organizations and the impact of communication on meeting their team's goals. All students were required to provide input for these informal reports and therefore gained confidence speaking in front of a group every week.

In an effort to monitor the extent of interaction between the team (as well as track individual student participation) and the organization, each team was required to log all communication with the organization and submit this $\log$ to the professor each week. One team member was responsible for collecting, compiling and submitting the weekly log for their team using an Excel ${ }^{\circledR}$ template created by the professor. Teams could submit the log electronically or in hard copy format. The Excel ${ }^{\circledR}$ template is shown in Chart 2.

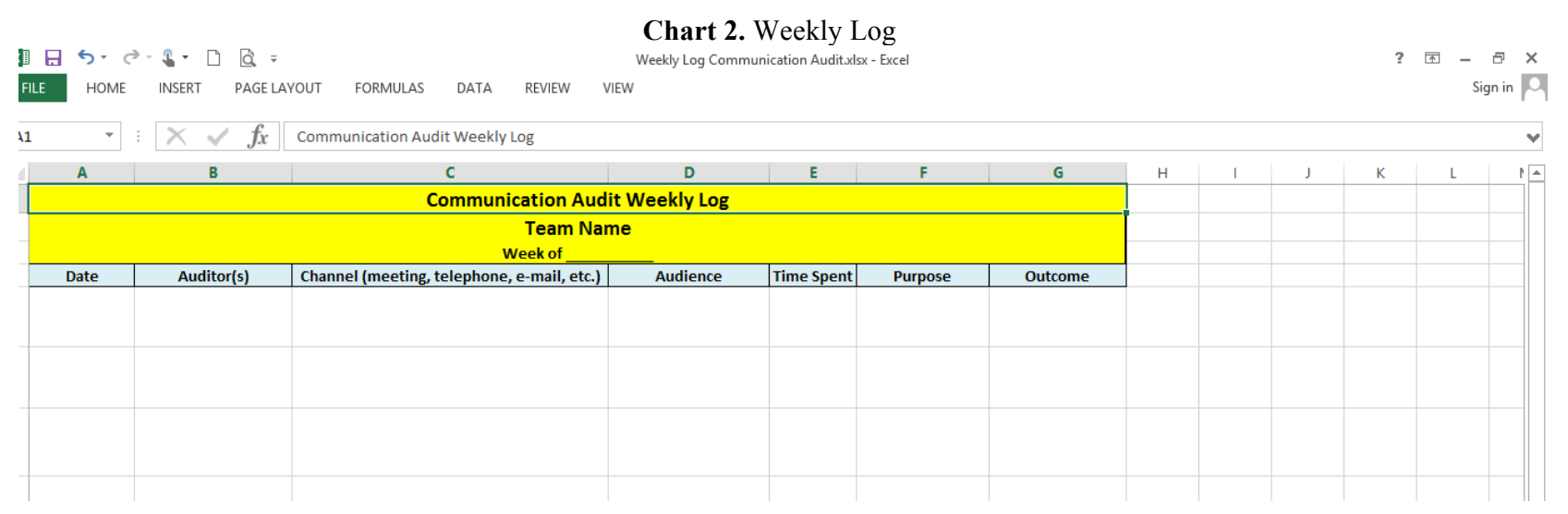

As the students began the project, they were required to meet with the designated contact person to learn about the organization. This included developing an agenda and scheduling a meeting time when all team members could attend. Each team was then required to submit a summary of the organization - including mission, objectives, 
programs, employees (organizational chart), etc. Teams were encouraged to collect as much documentation about the organization as was available to them.

The teams then scheduled a meeting with all staff for the purpose of introducing themselves and reviewing the audit process and its expectations. This meeting was critical to gaining acceptance and support from the employees. Organization leaders were expected to be present at this meeting to introduce the student team and reinforce the goals of the audit. Employees needed to understand that the audit was not an evaluation of their performance; rather, the results would be analyzed in aggregate to identify overall strengths as well as areas for improvement related to communication for the organization.

Each team gathered both quantitative and qualitative data. Based on the initial meetings, the teams developed their own questionnaire using The Downs-Hazen Communication Satisfaction Questionnaire (Downs \& Adrian 2004) as a model. Most of the teams asked employees to respond to the questionnaire in hard copy format, but a few teams used Qualtrics ${ }^{\mathrm{TM}}$ or in-house software.

After analyzing the survey results, audit teams prepared for individual interviews and/or focus groups to further explore communication issues. In preparation for these sessions, teams developed interview guides. Additional data collection methods were used by some teams when they believed there were areas that needed further exploration. For example, one team conducted an ECCO (Episodic Communication Channels in Organizations) analysis to determine the efficacy of an announcement using e-mail.

Once all data was analyzed and interpreted, conclusions and recommendations were developed and included in the team's final written report. Each team delivered a 30-minute presentation to the organization during the last week of the semester at the University. All students were required to participate in their team presentation.

\section{Communication Audit 2}

As mentioned earlier, the second time the course was offered, the University had just announced an Academic Quality Improvement Program (AQIP) Action Project entitled, Developing Feedback Mechanisms and Enhancing Campus Leadership Communication. The co-chairs of the Action Project Task Force for the University requested that the MBA communication class conduct a communication audit as the initial component for this project. This was a massive task given the 1,200 university employees, but also an excellent learning experience.

The president of the University announced this AQIP action project and explained the communication audit in his convocation speech at the beginning of the academic year. He sent a follow-up e-mail to all employees a month later asking for their participation in collecting data to identify campus communication strengths, weaknesses and obstacles.

To manage the audit, the 17 students in the class were divided into teams and each team was assigned one of the three divisions within the University: President's Division, Finance and Administration Division and Academic Affairs Division. The Academic Affairs Division was further divided into two subgroups because of the size: (1) faculty and staff and (2) deans, department heads and directors. Student teams were comprised of between three to five students based on the size of their assigned division.

Downs and Adrian's (2004) book was again required reading and students completed it prior to Week 6. The timeline shown in Chart 1 was followed with slight modifications to accommodate the large number of participants and scheduling issues.

Using the University's organization chart, each audit team identified leaders and employees within their assigned division. Student teams interviewed a sampling of these people to learn their perceptions of communication strengths and opportunities for improvement. The interviews were exploratory in nature to gain an understanding of the structure of communication within the division. 
Guest speakers attended class sessions early in the semester to prepare students for collecting quantitative data. Because an online survey would be administered, the Associate Vice President of Institutional Research conducted a training session on creating and administering online surveys using Qualtrics ${ }^{\mathrm{TM}}$ and a business research professor helped the students with techniques for developing survey items. The Downs-Hazen Communication Satisfaction Questionnaire (Downs \& Adrian 2004) was used as a template to develop the communication survey.

The class spent approximately one month writing and revising questions for the survey. This was accomplished during the weekly class sessions. The survey was then pilot tested by all MBA students, the AQIP cochairs, the University's Outcomes Assessment Coordinator and an undergraduate business research class. One student was responsible for completing the University's Application for Review of Research Involving Human Subjects and securing Institutional Review Board approval. All students completed the CITI Human Subjects Research Training Course as required by the University.

When the survey was launched five weeks into the 15 -week semester, an e-mail was sent from the class professor to employees emphasizing the need for their input in analyzing the University's communication strengths, obstacles and areas for improvement. The e-mail included a link to the online survey and participants were asked to click on the link to complete the survey. Employees were assured that participation was voluntary and anonymous and that all responses were completely confidential; reporting would be restricted to an aggregate level that would prevent the identification of individuals or groups of employees. Qualtrics ${ }^{\mathrm{TM}}$ includes an option for maintaining anonymity. The survey was open for two weeks and two reminder e-mails were sent during this period.

The population for this study consisted of all 1,210 employees; 309 completed all questions while 39 started the survey, but did not complete it in its entirety. These results represented a response rate of 29 percent.

Both quantitative and qualitative data were collected from the completed surveys. A new team was convened to interpret and analyze the survey results. Students were asked to volunteer for this team based on their expertise and areas of interest. The statistics team was divided into two subgroups: (1) a qualitative group, which analyzed written responses and identified general themes, and (2) a quantitative group, which analyzed the questions with a predetermined number of response options. The quantitative team utilized Qualtrics ${ }^{\mathrm{TM}}$, StatTools ${ }^{\mathrm{TM}}$ and Microsoft Excel ${ }^{\circledR}$ to analyze the data.

Using the general themes from the qualitative feedback, the original divisional teams conducted focus groups. The purpose of the focus groups was to obtain an in-depth understanding of communication within the University. Focus group participants elaborated on and supported many common themes discovered from the survey results. Managers and supervisors attended separate focus group sessions from their subordinates to promote an open environment and to gain as much honest information as possible.

The graduate student teams sent e-mail invitations to all potential participants to participate in a focus group. Some prospective participants were also contacted via phone or campus mail; others were requested directly by their supervisors to participate.

After the focus groups were completed, the teams combined feedback from the interviews, survey and focus group discussions. The entire class then convened for the purpose of reviewing all results and developing conclusions and recommendations. A final written and oral report was presented to University administrators and the AQIP Task Force during the last week of the semester. Of the 17 students in the class, five volunteered to participate in the oral presentation with each of the five delivering one part; the remaining 12 were responsible for writing the final report.

\section{STUDENT OUTCOMES}

Integrating a communication audit in the MBA communication class - using either small or large organizations - results in significant benefits for graduate students. The following discussion highlights the documented student outcomes as a result of this project. 


\section{Teamwork Skills}

Participating as part of a group in auditing any organization (but particularly institutions with over 1,000 employees) required students to exercise a great deal of cooperation and teamwork. To succeed in their respective assignments, students were forced to be flexible and cooperate with their teammates in such things as scheduling meetings, interviews, and focus groups, creating surveys, analyzing data, writing reports and presenting the final report. They were also required to practice patience with both their colleagues and stakeholders who did not always perform as desired. These attributes are among those characteristics that employers often cite as highly desirable in employees (Klaus, 2010).

There were two expected student outcomes related to teamwork: to demonstrate effective communication when leading groups and teams and to demonstrate effective strategies for managing individual and team conflict. Informal methods were used to provide feedback on teamwork during the semester. Every few weeks, time was set aside during class for each team to engage in an open discussion about how effectively their team was working. At the end of the semester, students were asked to complete a formal team evaluation form (see Chart 3 ).

During the first few weeks of the semester in Course 1, the professor provided samples of team evaluation instruments found online and the students reviewed those instruments. The class as a whole adapted one that was created by the Mathematics Department at the University of Michigan and at the Integrated Pest Management class at Cornell. Students in the other three courses adopted the same instrument used by the students in Course 1 . The professor collected the completed instruments, compiled the numeric ratings and comments and gave each student a summary of the evaluation from their team members. These evaluations were only based on team member feedback and did not include an evaluation by the professor. The ratings, however, were part of the students' course grade.

The team evaluation rubric was separated into two components. The first section labeled personnel evaluation required each student to evaluate each team member on 11 criteria on a 5 -point scale $(5=$ Excellent, $1=$ Unacceptable). It was expected that 100 percent of the students would receive scores of 4.0 or above on all 11 areas in the first section of the rubric. That goal was met by all students in all four courses.

Although all of the criteria on the evaluation were important, one of the items in the personnel evaluation section related specifically to communication within the team: "Communicates clearly: generates ideas, listens and gives feedback." It was expected that 80 percent of the students would receive scores of 4.0 or above on this item in the personal evaluation section of the rubric. For Course 1,10 out of 14 students (71 percent) met the 4.0 expectation. It is interesting to note, however that the four students who did not meet the 4.0 minimum were all members of the same team. For Course 2, 17 out of 18 students (94 percent) met the 4.0 minimum goal; for Course 3, 11 out of 11 students ( 100 percent) met the minimum goal; for Course 4,18 out of 18 students (100 percent) met the minimum goal.

The second part of the rubric asked students to evaluate the team's performance on a variety of dimensions. One of the dimensions was communication. The 5-point rating scale indicated a rating of 5 meant "full, open and spontaneous" while a rating of 1 meant "don't keep other members informed." Again, the expectation was that 80 percent of the team members would receive a score of 4.0 or above. In Course 1,12 out of the 14 students $(85.7$ percent) rated the team communication as 4.0 or above; in Course 2,15 out of 17 students ( 88 percent) rated the team communication as 4.0 or above; in Course 3, 7 out of 9 students ( 78 percent) rated the team communication as 4.0 or above and in Course 4, 17 out of 18 students (94 percent) rated the team communication as 4.0 or above.

A separate item on the second part of the rubric asked students to evaluate their team's ability to handle conflict/differences. This item related specifically to the student outcome "demonstrate effective strategies for managing individual and team conflict." The 5-point rating scale indicated that a rating of 5 meant "explore and solve conflicts" and a rating of 1 meant "avoid or ignore." Again, the expectation was that 80 percent of the team members would receive a score of 4.0 or above. In Course 1,12 out of 13 students ( 92.3 percent) met the objective; in Course 2, 17 out of 17 students (100 percent) met the objective; in Course 3, 8 out of 9 students ( 88.9 percent) met the objective, and in Course 4, 15 out of 18 students ( 83 percent) met the objective. Therefore, all students met the goal. 
Chart 3. Team Evaluation Form*

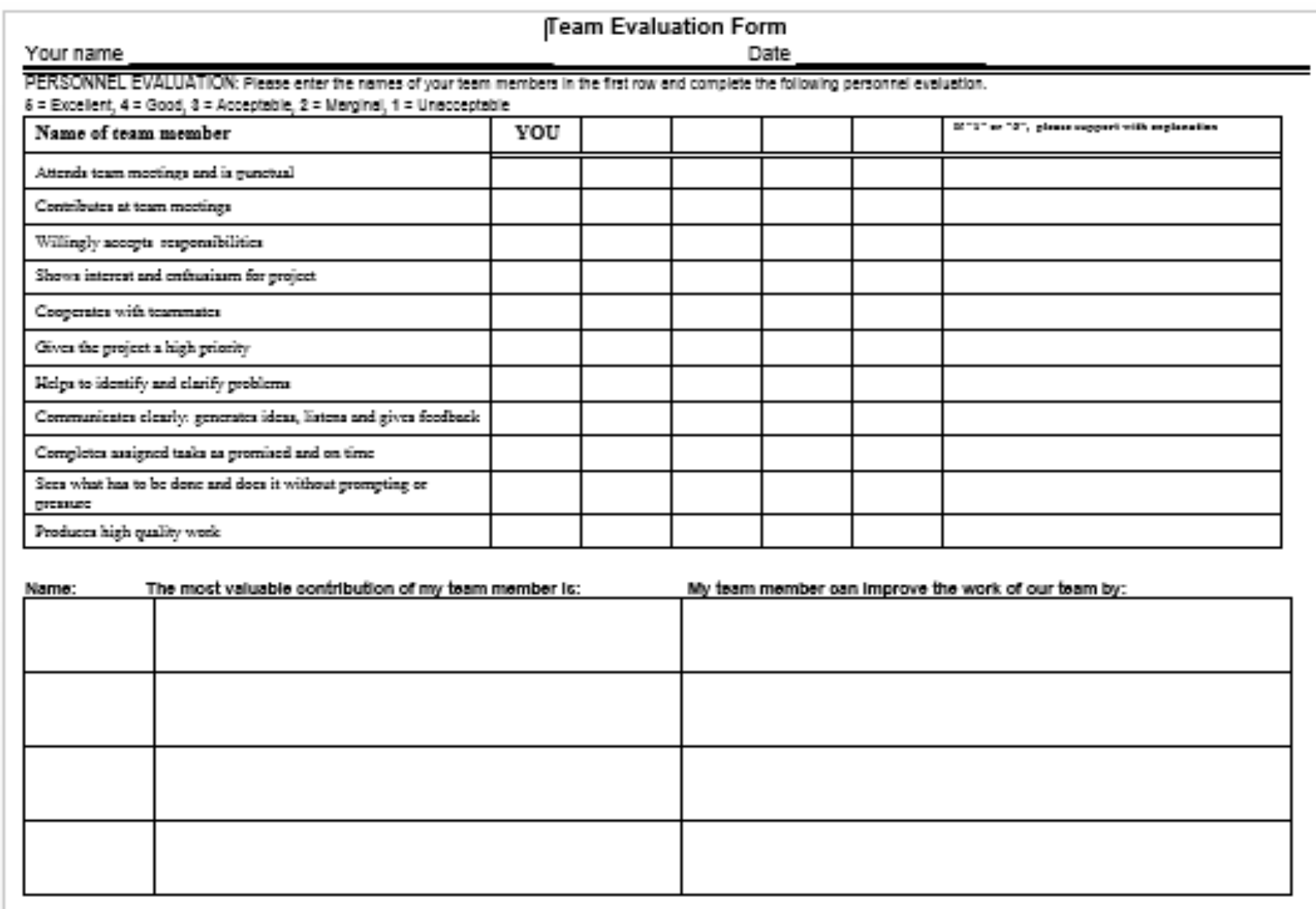

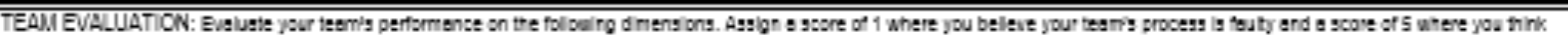
your tean is furctioning wel. [6: Hohly effective - 1: Inellective]

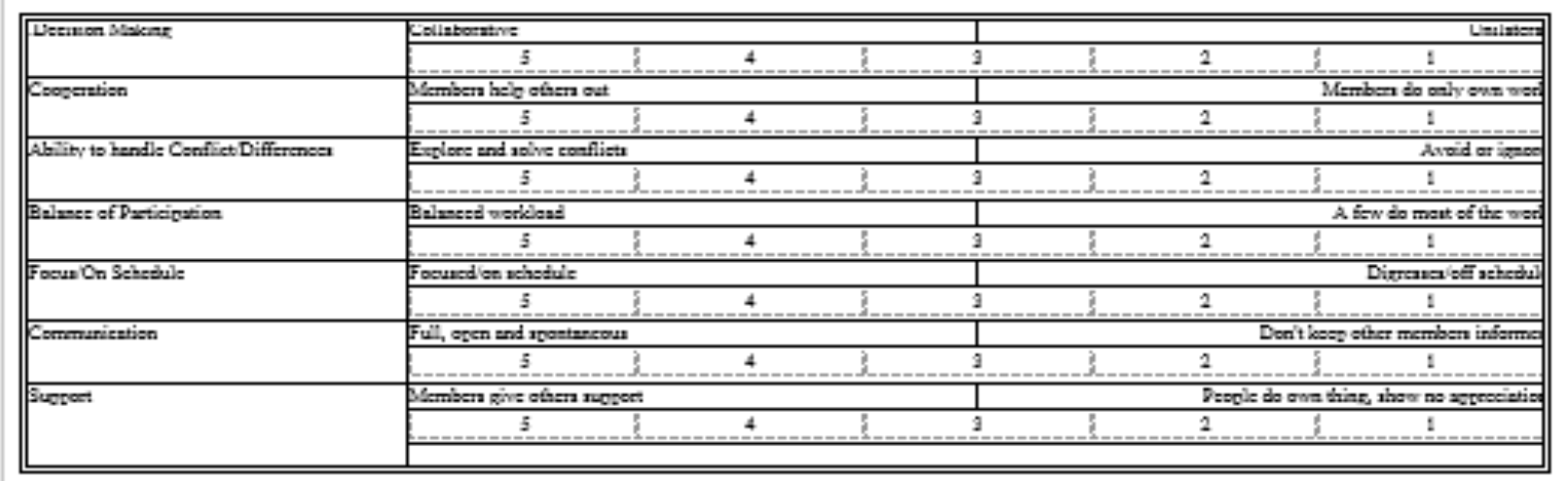

*Adapted from an instrument created by the Mathematics Department at the University of Michigan and at the Integrated Pest Management class at Cornell

In addition to student self-assessment of teamwork, a section on the grading rubric for the final presentation (see Chart 4) included a component that evaluated teamwork in the context of team delivery. The rubric considered smooth transitions, logical sequencing, evidence of practice, ability to handle audience questions, and consistent appearance and enthusiasm among the team. This section was worth 15 points and it was expected that 80 percent of 
the teams would score 13 or more points on this section. Throughout all course sections, 100 percent of the students met this goal.

Chart 4. Team Delivery Section from Oral Presentation Rubric

\begin{tabular}{|c|c|c|}
\hline \multicolumn{3}{|c|}{ Team Delivery } \\
\hline (15 pts) & (13-14 pts) & $(<13$ pts $)$ \\
\hline $\begin{array}{l}\text { Team member transitions organized and } \\
\text { seamless }\end{array}$ & $\begin{array}{l}\text { Team member transitions fairly } \\
\text { organized. }\end{array}$ & $\begin{array}{l}\text { Team member transitions somewhat } \\
\text { disorganized. }\end{array}$ \\
\hline $\begin{array}{l}\text { Logical sequencing and flow among } \\
\text { team members }\end{array}$ & $\begin{array}{l}\text { Team member sequencing ok, but could } \\
\text { have been smoother/more balanced. }\end{array}$ & $\begin{array}{l}\text { Rough, illogical sequencing among team } \\
\text { members. Very little flow. }\end{array}$ \\
\hline Team practice evident & Team practice likely. & Team practice no evident. \\
\hline $\begin{array}{l}\text { Questions from audience handled } \\
\text { smoothly and professionally as a team } \\
\text { (plan was evident for responding to } \\
\text { questions) }\end{array}$ & $\begin{array}{l}\text { Questions from audience handled fairly } \\
\text { well, but some hesitation from team on } \\
\text { who would answer the question. }\end{array}$ & $\begin{array}{l}\text { Team members clearly uncomfortable } \\
\text { with questions from audience. Evident } \\
\text { that team had not planned how to handle } \\
\text { questions. }\end{array}$ \\
\hline $\begin{array}{l}\text { Appearance and enthusiasm highly } \\
\text { consistent among team. }\end{array}$ & $\begin{array}{l}\text { Appearance and enthusiasm consistent } \\
\text { among team. }\end{array}$ & $\begin{array}{l}\text { Little consistency in appearance and } \\
\text { enthusiasm among team. }\end{array}$ \\
\hline
\end{tabular}

For Course 2, all students were required to work in several different teams throughout the course of the audit. Not only did students learn how to work well with different personalities, but they also learned how to coordinate and work toward different objectives. For example, in the University-wide communication audit (Course 2), each new team consisted of different students with a different objective than the previous team. Specifically, Student A could have been on a team with Students B, C, and D with the task of capturing top leadership's perspective of communication on campus, and then been on a new team with students $\mathrm{E}$ and $\mathrm{F}$ proofreading a report. Students will face similar situations in the workplace and excel because of this experience. In addition, participation in the audit experience may have the added benefit of easing the transition to the workplace environment for students who gain valuable exposure to the internal workings of a real world institution.

For Courses 1 and 2, the Team Evaluation Form was completed at the end of the semester. However, the professor recognized that teams needed more formal feedback prior to the end of the project. During Courses 3 and 4 , teams were required to complete the formal team evaluation in the middle of the semester as well as at the end of the semester. If a team had issues, they would have time to make positive changes for the remainder of the project. During Course 3 and Course 4, the Team Evaluation Form was completed at the middle of the semester and at the end of the semester. Although it was expected that all student averages on the personnel evaluation section of the form would increase, interestingly for Course 3, 66 percent of the student averages went down slightly. It is unclear whether the students felt the team was not working together as well at the end of the semester or if they used their original ratings when completing the second evaluation. During Course 4, 33 percent of the student averages went down slightly. In order to measure team effectiveness, it would be important to remind students to reference the midsemester ratings when making their final comparisons.

\section{Writing Skills}

The ability to reduce relevant information to its most elemental form and to communicate that information in writing is essential in any business realm. The audit experience required students to accumulate a great deal of information, distill it to its most salient components, and convey that information in a written report that could be used as part of an action plan. As Downs and Adrian (2004) emphasize, the final report must be a superb form of communication about communication (p. 247).

Students were held to this standard and expected to deliver a high-quality document that decision makers would find beneficial. This document was evaluated according to an additional student outcome which was to "demonstrate effective written business communication skills." The Communication Audit Report Rubric (see Chart 5) was used to evaluate the final audit report with regard to report content, front and back matter, report design, audience adaptation, report organization, writing quality and source citation style. The expectation for the 
final written report was that 100 percent of the students would score 80 percent or above (120 points; the equivalent of meets or exceeds expectations) on the written report rubric. Not surprisingly, 100 percent of the students in all four courses met the overall score threshold.

Chart 5. Communication Audit Report Rubric

BUS 500, Fall 2014

Team:

Date:

\begin{tabular}{|c|c|c|c|c|}
\hline \multicolumn{2}{|l|}{ leam: } & \\
\hline Performance Element & Criteria & $\begin{array}{c}\text { Exceeds } \\
\text { Expectations } \\
\end{array}$ & $\begin{array}{c}\text { Meets } \\
\text { Expectations } \\
\end{array}$ & $\begin{array}{c}\text { Below } \\
\text { Expectations }\end{array}$ \\
\hline $\begin{array}{l}\text { Report Content } \\
\text { - } \text { Purpose } \\
\circ \text { Client description } \\
\circ \text { Historical background } \\
\circ \text { Limitations } \\
\text { - } \text { Procedures } \\
\circ \text { Data collection } \\
\text { techniques } \\
\text { - } \text { Raw Data } \\
\circ \text { Separate sections fro } \\
\text { each kind of data } \\
\circ \text { Descriptive, } \\
\text { nonevaluative } \\
\circ \text { Data problems } \\
\text { explained } \\
\text { - Analysis } \\
\circ \text { Analytic procedures } \\
\circ \text { Results summarized } \\
\circ \text { Tables with narrative } \\
\text { descriptions } \\
\text { - Conclusions } \\
\text { Recommendations }\end{array}$ & $\begin{array}{l}\square \text { New, interesting to } \\
\text { reader(s) } \\
\square \text { Valid } \\
\square \text { Objectively analyzed } \\
\square \text { Accurately present } \\
\square \text { Comprehensive - indepth } \\
\square \text { No irrelevant or trivial } \\
\text { details } \\
\square \text { Variety of research } \\
\text { Sources } \\
\square \text { Realisitic, practical ideas } \\
\square \text { Relevant examples/details } \\
\text { meaningful to client } \\
\square \text { Manageable, meaningful } \\
\text { conclusions } \\
\square \text { Related to goals of } \\
\text { organization }\end{array}$ & (68-75 pts) & (60-67 pts) & $(<60 \mathrm{pts})$ \\
\hline $\begin{array}{l}\text { Front Matter and Back } \\
\text { Matter } \\
\text { - Title Page } \\
\text { - Executive Summary } \\
\text { - Appendices } \\
\quad \text { O Copies of Instruments }\end{array}$ & $\begin{array}{l}\square \text { Comprehensive } \\
\square \text { Accurate } \\
\square \text { Complies with standard } \\
\text { formats }\end{array}$ & (9-10 pts) & (7-8 pts) & $(<7 \mathrm{pts})$ \\
\hline $\begin{array}{l}\text { Report Design } \\
\text { - Font size, style } \\
\text { - Spacing, pagination } \\
\text { - Margins } \\
\text { - Headings } \\
\text { - Visual aids }\end{array}$ & $\begin{array}{l}\square \text { Easy to read } \\
\square \text { Complies with standards } \\
\text { for business document } \\
\text { design } \\
\square \text { Pleasing appearance } \\
\square \text { Graphics are accurate, } \\
\text { coherent } \\
\square \text { Graphics are appropriate } \\
\text { for content }\end{array}$ & (14-15 pts) & (12-13 pts) & $(<12 \mathrm{pts})$ \\
\hline $\begin{array}{l}\text { Audience Adaptation } \\
\text { - Language } \\
\text { - Content } \\
\text { - Anonymity }\end{array}$ & $\begin{array}{ll}\square & \text { Directly addresses } \\
\text { reader(s) } \\
\square & \text { Motivates reader toward } \\
\text { desired outcome } \\
\square \quad \text { Uses language familiar to } \\
\text { reader(s) } \\
\square \text { Maintains anonymity of } \\
\text { participants }\end{array}$ & (9-10 pts) & (7-8 pts) & $(<7 \mathrm{pts})$ \\
\hline
\end{tabular}


(Chart 5 continued)

\begin{tabular}{|c|c|c|c|c|}
\hline Performance Element & Criteria & $\begin{array}{c}\text { Exceeds } \\
\text { Expectations } \\
\end{array}$ & $\begin{array}{c}\text { Meets } \\
\text { Expectations }\end{array}$ & $\begin{array}{c}\text { Below } \\
\text { Expectations }\end{array}$ \\
\hline $\begin{array}{l}\text { Report Organization } \\
\text { - Title Page } \\
\text { - Table of Contents } \\
\text { - Executive Summary } \\
\text { - Introduction } \\
\text { - Procedures, Raw Data } \\
\text { and Analysis } \\
\text { - Conclusions } \\
\text { - Recommendations } \\
\text { - Appendices }\end{array}$ & $\begin{array}{l}\square \text { Clear main ideas } \\
\square \text { Logical sequence of topics } \\
\square \text { Balanced partition of } \\
\text { topics } \\
\square \text { Uses transitions, } \\
\text { summaries }\end{array}$ & $(9-10 \mathrm{pts})$ & (7-8 pts) & $(<7 \mathrm{pts})$ \\
\hline $\begin{array}{l}\text { Writing Quality } \\
\text { - Style and tone } \\
\text { - Mechanics, spelling } \\
\text { - Usage } \\
\text { - Grammar } \\
\text { - Language/diction } \\
\end{array}$ & & $(23-25 \mathrm{pts})$ & $(21-22 \mathrm{pts})$ & $(<21 \mathrm{pts})$ \\
\hline $\begin{array}{l}\text { Source Citation Style } \\
\text { (APA) } \\
\text { - In-text } \\
\text { - References list }\end{array}$ & $\begin{array}{l}\text { Complete (source is } \\
\text { discoverable }\end{array}$ & (5 pts) & (4 pts) & $(<4 \mathrm{pts})$ \\
\hline
\end{tabular}

Final report rubrics were returned to the students and copies were not retained for Courses 1,2 and 3 so achievement on individual performance elements could not be reported. However, for Course 4, the most recent course, results were retained. These results are as follows. On four performance elements (report content, front and back matter, writing quality and source citation style), 100 percent of the groups did meet or exceed expectations. In three performance areas (report design, audience adaptation and report organization), 75 percent of the groups achieved a rating of meet expectations or exceed expectations. In future semesters, this information will be recorded and analyzed so that student outcomes can be reported in more detail.

\section{Presentation Skills}

An additional outcome of the audit was that students were expected to "demonstrate effective oral techniques in informal interactions and formal presentations." Students participated in informal interactions throughout the semester when working with the organizational leaders, organization employees, and other team members. Each team was informally asked to discuss their progress and concerns at weekly course meetings. After Courses 1 and 2, it was apparent that all students were not participating equally. To encourage balanced participation, the instructor began logging frequency of comments as a component of the final grade. Students evaluated their team member' informal interactions as part of the Team Evaluation Form.

At the end of the semester, students made presentations of their audit results to stakeholders. The Team Oral Presentation Rubric shown in Chart 6 was used to evaluate the final presentations. This rubric was used to evaluate the presentation content, organization, style, communication/visual aids, individual delivery, and team delivery. Because this was a graduate course, the expectation was that 90 percent of the students would perform at the "meets expectations" level or "exceeds expectations" level (earn a total score of 60 or above). During all four courses that expectation was met by all but one student. 
Chart 6. Oral Presentation Rubric

Team Oral Presentation Rubric

Communication Audit, BUS 500, Fall 2014

Team:

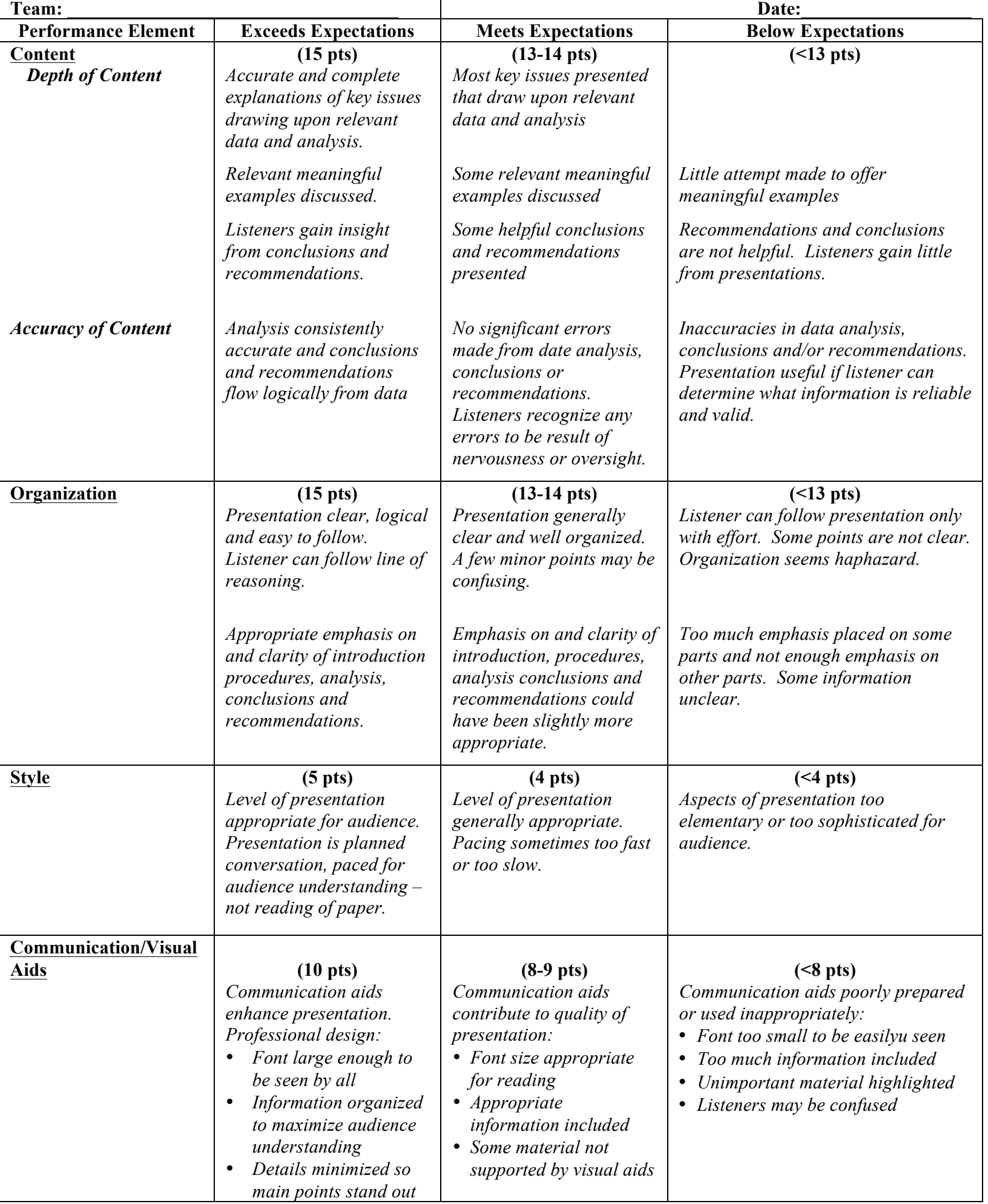


(Chart 6 continued)

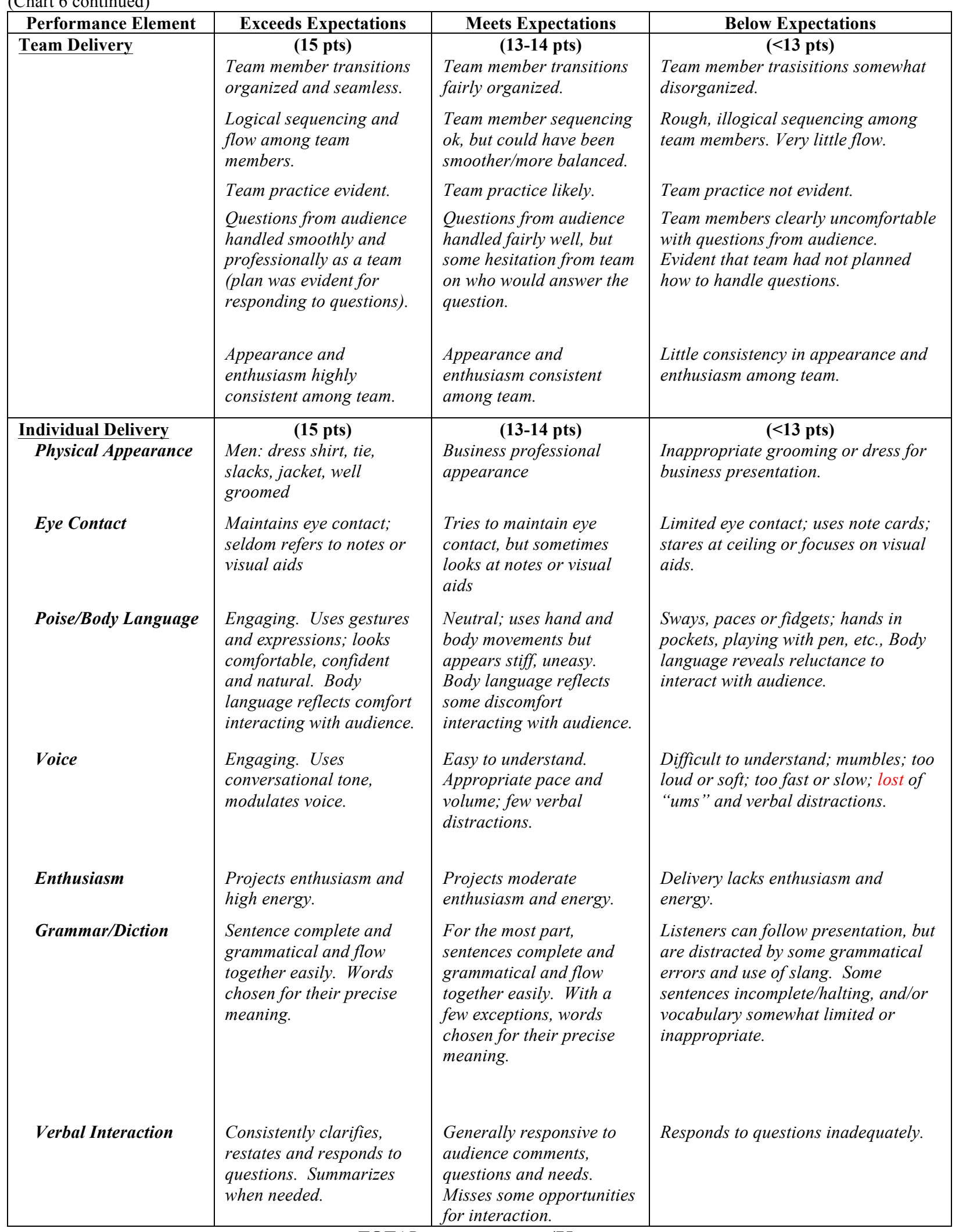

TOTAL: /75 pts 
Final oral presentation rubrics for Courses 1, 2 and 3 were returned to the students and copies were not retained. For Course 4, the results are as follows. In three of the group performance elements (content, organization and team delivery), 100 percent of the groups met the objective of "meets expectations" or "exceeds expectations." In two objectives (style, and communication/visual aids), 75 percent of the groups met the objective of "meets expectations" or "exceeds expectations." While most of the rubric evaluated team scores, there was one section that reported individual scores. Again, the hope was that 80 percent of individual students would "meet expectations" or "exceed expectations." For Course 4, 13 of the 18 students (72 percent) achieved the intended objective. In future semesters, that information will be recorded and analyzed so that student outcomes can be assessed in more detail.

In making the presentation, students not only had to organize and prepare coherent verbal presentations, they were forced to deal with the anxiety and uncertainty that comes with imparting information that may not be pleasant or what the stakeholders hoped to hear. This is the type of anxiety that can only be conquered by exposure and experience. Most employers undoubtedly prefer employees who can demonstrate at least minimal familiarity with the stress of this situation, which students who have practiced it in the auditing experience can claim. In addition, the experience gained by enduring the stress of this type of situation in a real work place environment was something most all students acknowledged was excellent preparation for any professional position.

\section{ADDITIONAL BENEFITS}

Integrating a communication audit in the MBA communication results in additional benefits for graduate students. The following discussion describes additional job-related competencies that students develop as a result of this project.

\section{Research Skills}

Another unique opportunity students experienced because of the communication audit is the formal and at times rigorous process of research. Students were tasked with collecting raw data, performing analysis, and developing conclusions while working within the legal confines of performing research involving human subjects. Formal processes such as completing a Collaborative Institutional Training Initiative (CITI) training module or applying for approval for research with the Institution Review Board (IRB) prepares graduates to excel following formal company policies and procedures.

As part of their auditing experience, students were required to conduct independent research and develop and administer a professional survey tool. The ability to determine what information was needed to conduct the audit, how to solicit it in an objective way and verify the integrity of that research, is an experience that is directly transferable to the business workplace. Although team research skills were evaluated informally through weekly course discussions there was no formal process embedded in the course.

\section{Interviewing Skills}

Student teams conducted interviews with many employees to understand the nature and structure of communication within the audited institution. This gave them a great deal of interviewing experience, which resulted in significantly increased confidence in personal interactions with stakeholders as well as competency in effectively soliciting the information necessary for a successful audit.

Students learned the preparation necessary for conducting a successful interview as they were required to develop interview and focus group guides that included an agenda as well as specific questions to ask and information to share.

\section{Statistical and Software Skills}

Students gained real world experience using analytical tools that are commonly found in workplace settings. An employer who hires these graduates will find they are comfortable using Qualtrics ${ }^{\mathrm{TM}}$, StatTools ${ }^{\mathrm{TM}}$ and Microsoft Excelß. Many students had no formal experience using statistical software prior to this course. By the 
end of the semester course all students had been exposed to analytical tools. Not only are they adept at using these tools, the audit experience resulted in the ability to conduct relevant real world analysis of the data that emerged.

\section{Analytical Skills}

The ability to synthesize information and produce a summary that provides useful, actionable information is something that all employers seek. Student auditors were required to take the information they accumulated, analyze it and produce a final report that demonstrated original thought, problem solving abilities, and the ability to construct effective arguments to defend their recommendations. Critical thinking is crucial to all workplace environments and any occupational endeavor graduates undertake.

\section{RECOMMENDATIONS}

Based on our experiences conducting communication audits in MBA communication courses, a number of suggestions are offered to improve the experience for the students, the professor, and the audited organization.

For the first three audits, the professor identified the organizations to be audited, but required the teams to secure an organization during the fourth course. This requirement proved to be a valuable learning experience and we highly recommend this practice as many students will be expected to step outside of their comfort zone by 'cold calling' and interacting with professionals they have never met. In order to meet the audit deadlines, students will have to begin this process immediately when the class begins which will require motivation and initiative - two valuable soft skills.

While the University-wide audit was a valuable experience for the students, the number of participants became unmanageable at times. Students were required to work in multiple teams in order to accomplish the massive workload. While this is beneficial in many ways, including learning how to work with different team members, the smaller organizations offered the advantage of allowing every student to participate in all aspects of the audit. For example, every student was required to participate in analyzing and interpreting all quantitative and qualitative data, delivering the oral presentation and in writing the final report.

Some teams became frustrated with gaining access to employees for the purpose of conducting interviews and focus groups. While this expectation was emphasized in the initial contact with the organization leader, the professor may need to intervene earlier in the process if this becomes problematic and stalls the process. Employees also need to be reminded frequently throughout the audit that all information is anonymous and confidential and is not intended as an evaluation of their performance. While this was also communicated during the initial phase of the audit, periodic reminders during the data collection phase may be helpful in sustaining cooperation.

Schedules with deadlines for completing each phase of the audit are critical to a successful outcome. However, the deadlines cannot be so rigid that the quality of the audit suffers if unforeseen circumstances arise. Deadlines must be identified, but because the project involves "real" businesses, you and your students cannot always control the process. This is a valuable skill that students will learn as they are transitioning from the stringent semester schedule of university life to the often unpredictable schedule of the "real world."

A valuable component of the course was for teams to informally report on their progress each week. Students learned from each other and offered suggestions based on their own experiences. Setting aside time in class for this interaction is critical.

Requiring log sheets for documenting weekly interactions with employees is also important. Students need to be held accountable for upholding their share of the workload and the log provides evidence to the professor about individual participation. At the very least, the act of having to submit a log may provide motivation for some students to participate at a higher level. 
Similarly, requiring team members to evaluate each other is extremely important. Several different methods were used to provide this opportunity. Every few weeks, time was set aside during class for each team to engage in an open discussion about how effectively their team was working. Questions the students were asked to address consisted of:

1. What do you believe our team is doing well?

2. How do you believe our team can improve?

3. What do you believe you are contributing to the team?

4. What can you do to improve the work of the team?

A more formal evaluation was done at the middle of the semester and at the end of the semester for Courses 3 and 4 . We believe this was a valuable process as team members often will document problems on a formal evaluation that they don't feel comfortable discussing face-to-face. Many underlying issues were brought to light using this instrument and served as a spring board for open discussions about group problems that needed to be resolved before the end of the project. To ensure that a decrease in team member scores from midsemester to the end of the semester is purposeful, it is recommended that the midsemester evaluation be returned and used when completing the final evaluation.

Teams were required to do a dress rehearsal of their formal presentation to the organization decision makers a week prior to the presentation. This rehearsal was done in front of the entire class with the expectation that all students (as well as the professor) offer constructive feedback for improvement. These rehearsals proved to be invaluable during all four courses. This class session often extended hours beyond the expected end time as the students were very eager to continue practicing until they "got it right."

Finally, we recommend that at the conclusion of the audits, data be gathered from the organization to help evaluate team performance. This could be done by means of a questionnaire or face-to-face interview between the professor and the contact person within the organization. While this information would not necessarily be used to evaluate student performance (i.e., grades), the information may be particularly helpful in evaluating outcomes and improving the process for future course projects.

\section{CONCLUSION}

Providing students with an educational experience that demands and develops skills in the areas of communication, teamwork, interviewing, research and analysis will result in prized graduates who will be much more marketable to employers. Not only will they have a better chance of convincing a prospective employer to hire them, their lifelong refinement of these skills will enhance their job performance and long term career prospects. Robles (2012) reminds us that educators face a difficult challenge providing students with the type of experience that will help them to develop these prized skills. We believe that the communication audit project is an excellent way to provide students with these valuable skills instead of just reading about them in a textbook. When engaged in a communication audit, students live every aspect of communication and observe the strengths, weaknesses and results of communication as they happen within an actual organization. Students experience having to tolerate ambiguity and accept that there may be questions for which there are no single right answers - just like in the business world. They must assume direction and responsibility for their audits and must expect accountability from their teammates. They also must engage in appropriate professional conduct at all times. This project becomes a win-win not only for the graduate students as they develop these skills and abilities, but also to the audited enterprise, which receives the benefit of valuable and free managerial advice. The value of this type of experience was summarized well by an international student in his final evaluation of his team:

Looking back, I almost gave up on the work of this group at first - I felt overwhelmed to communicate with them. But now, I feel so lucky that I have such a GREAT team. This team experience was totally different than I ever had before, even in other MBA classes. Every team member had a different role to play and he/she fit into his/her role perfectly in the end and I cannot imagine that this project worked out so well. After our first rehearsal in front of all our classmates, I could feel everyone pull together and put all strengths on the same side and that power created a miracle. I knew that I could not let my team down. I 
learned from every team member, from different perspectives, and that is a most valuable experience that I could never learn from other classes. Lastly, I want to thank our professor who designed this fabulous study experience for everyone in our class. It was an unforgettable and incredible experience in America.

\section{AUTHOR INFORMATION}

Claudia Hart (Contact Author) is a professor of management in the College of Business at Northern Michigan University. She teaches managerial communication and training and development courses at both the undergraduate and graduate levels.

Margo Vroman is an associate professor of business law in the College of Business at Northern Michigan University. She teaches business law and cyber security courses at both the undergraduate and graduate levels.

Karin Stulz is an assistant professor of office information in the College of Business at Northern Michigan University. She teaches business procedures and software applications courses at the undergraduate level.

\section{REFERENCES}

Coffman, J. (2004). Strategic communication audits. Communications Consortium Media Center, Washington, DC. 17(2), 145-177. Retrieved from Sage Publications database.

Downs, C.W., \& Adrian, A.D. (2004). Assessing Organizational Communication. New York: The Guilford Press. Employers value communication and interpersonal abilities. (2004). Keying In, 14(3), 1-6.

Glenn, J. L. (2008). The "new" customer service model: Customer advocate, company ambassador. Business Education Forum, 62(4), 7-13.

Hargie, O., \& Tourish, D. (Eds.). (2009). Auditing Organizational Communication. New York, NY: Routledge.

Henderson, J.K. (2005). Evaluating public relations effectiveness in a health care setting: The identification of communication assets and liabilities via a communication audit. Journal of Health and Human Services Administration, 28(2), 282-322. http://www.jstor.org/stable/41288067

Klaus, P. (2010). Communication breakdown. California Job Journal, 28, 1-9.

Mumby, D. \& Stohl, C. (1996). Disciplining organizational communication studies, Communication Quarterly, 10, $50-72$.

Perreault, H. (2004). Business educators can take a leadership role in character education. Business Education Forum, 59, 23-24

Robles, M.M. (2012). Executive Perceptions of the Top 10 Soft Skills Needed in Today's Workplace. Business Communication Quarterly, 75(4), 453-465, DOI: 10.1177/1080569912460400

Scott, C., Shaw, P., Timmerman, C., Volker, F and Quinn, L. (1999). Using Communication Audits to Teach Organizational Communication to Students and Employees, Business and Professional Communication Quarterly, vol. 62 no. 4, pp 53-70.

Shelby, A.N., \& Reinsch, N.L. (1996). The communication audit: A framework for teaching management communication. Business Communication Quarterly, 59(2), 95-109.

Zorn, T. (2002). Forum introduction: Current uses, critical appraisals and future prospects. Management Communication Quarterly, 15, 439-441. 
NOTES 